\title{
Evaluating the Viability of Lactic Acid Bacteria and Nutritional Quality of Hibiscus Sabdariffa Stored Under Natural Condition
}

\author{
Eguono Esther Anomohanran ${ }^{1}$ \\ ${ }^{1}$ Department of Microbiology, Delta State University, Abraka, Nigeria \\ Correspondence: Eguono Esther Anomohanran, Department of Microbiology, Delta State University, Abraka, \\ Nigeria. E-mail: a_eguono@yahoo.com
}

Received: November 4, 2014

doi:10.5539/ijb.v7n1p116
Accepted: December 8, 2014 Online Published: December 14, 2014

URL: http://dx.doi.org/10.5539/ijb.v7n1p116

\begin{abstract}
The viability of lactic acid bacteria and nutritional quality of Hibiscus sabdariffa were investigated under ambient temperature to evaluate the health implication associated with the consumption of the beverage obtained from the plant. This was carried out by employing the pour plate method and the gravimetric technique of estimating the indigestible fibre in a beverage. The result obtained from the study showed that the viable bacteria counts increase steadily for the first six days of storage and decreased afterwards. The study also showed that isolates of Bacillus spp. Streptococcus spp. and Staphylococcus spp. were identified at the initial phase of the storage while isolates of Aspergillus spp., Geotrichum spp and Lactobacillus were identified in the later phase of the storage period. The study further showed that the $\mathrm{pH}$, carbohydrate, protein and vitamin $\mathrm{C}$ content increased gradually throughout the period of storage. The risk associated with the beverage could be reduced if at all stages from harvesting to selling, good hygienic conditions are imbibed. Hence the Hibiscus sabdariffa beverage could serve as a convenient substitute to carbonated drinks, which may not be affordable by a lot of people.
\end{abstract}

Keywords: Hibiscus sabdariffa, Roselle, Zobo, lactic acid bacteria, red calyces, beverage

\section{Introduction}

Hibiscus sabdariffa is a dicotyledonous and autogamous plant of the Malvaceae family. It is native to Africa and widely grown in tropical and subtropical regions of both hemispheres and many areas of India and parts of Asia, America and Australia (Sie et al., 2011). Hibiscus sabdariffa also known as Roselle is also found in many countries of the world which include Malaysia, Indonesia, Mexico and Nigeria. The high content of anthocyanins in the calyx of the plant makes it possible for the production of drinks and tea. The calyces are used for making fresh Roselle wine, jelly, gelatin, beverages, cakes, tea, marmalade, ices, ice-cream, butter, sauces and other desserts.

The Hibiscuss sabderiffa plant is also considered to have antihypertensive properties hence it has been used in the medical field as a diuretic, sedative and treatment of cardiac, nerve diseases, cancer, and liver disorders (Sie et al., 2011; Sengupta \& Banik, 2011; FIIRO, 2014). Study has also shown that the extract from this flower has demonstrated hypocholesterolemic properties (Sindi et al., 2014). It is also agreed that the concentrated Hibiscus sabdariffa beverages lower blood pressure in patients with hypertension and diabetes compared with black tea (Mckay et al., 2010).

The plant is used as a beverage that helps to lower the body temperature while the water extracts of hibiscus flowers are said to have a relaxing effect on the uterus and lower the blood pressure. Clinical evaluation has shown that the plant reduces cholesterol by a factor of $8-14 \%$ within a month (Lin et al., 2007). The solution obtained from the dried Roselle calyces is known to contain a lot of chemical constituents which include alkaloids, L-ascorbic acid, citric acid, anthocyanin quercetin and anisaldehyde.

The plant Roselle calyces are also rich in minerals such as calcium, magnesium, iron, potassium and sodium (Peter et al., 2014). The red calyces of the plant are increasingly exported and used as food colourings. The red calyx of the Hibiscus sabdariffa is the major component possessing the sour taste obtained from the beverage.

In Nigeria, the beverage obtained from the plant is produced from the red calyces and its consumption has gained wide popularity all over the country. However, the low shelf life of the drink produced by the traditional method has placed serious limitations on its general acceptance and consumption in Nigeria. Another factor which has limited its general acceptance is the growing concern that the crude extract from many of our natural plants are 
unsafe for consumption (Sulaiman et al., 2014). This is the reason why this study was carried out to evaluate the microbiological and nutritional properties of the crude extract from Hibiscus sabdariffa. This study will provide information on the risk associated with the storage of the beverage and how to overcome it.

\section{Materials and Methods}

\subsection{Collection of Plant Material}

Dried reddish petals of Hibiscus sabdariffa plant were obtained from the open market and transferred to the Microbiology Laboratory, Delta State University, Abraka, Nigeria in a polyethylene bag. The plant was prepared in accordance with the method explained by Sulaiman et al. (2014). In accordance with this method, $100 \mathrm{~g}$ of the dried flower was mixed with $1000 \mathrm{~cm}^{3}$ of water and boiled for 30 minutes to obtain the plant beverage. The crude extract was allowed to cool and then filtered using a clean sieve.

\subsection{Determination of Microbial Counts}

The viable bacteria counts were evaluated by pour plate method using $1 \mathrm{ml}$ of serially diluted beverage samples in Nutrient agar and incubated at room temperature for 48 hours (Cheesbrough, 2002). Duplicate plates were made for each dilution. The yeast and mould counts were determined using Potato Dextrose Agar incorporated with antibiotics and incubated at room temperature for 72 hours (Cheesbrough, 2002). Pure isolates were obtained by picking discrete colonies from the growth media plate. The colonies were then subculture by streaking onto fresh growth media plates until pure isolates were obtained. The isolates were then transferred onto agar slants of the same medium as stock culture. They were stored in a refrigerator at $0-4^{\circ} \mathrm{C}$ from where they were taken for identification test.

\section{$2.3 \mathrm{pH}$ Test}

The $\mathrm{pH}$ test was carried out by using the HI99131N pH meter manufactured by Hanna Instrument. A phosphate buffer solution of $\mathrm{pH} 7.02$ was used to standardize the meter at room temperature before the readings were taken.

\subsection{Determination of Carbohydrate, Vitamin C and Protein Content}

The test for carbohydrate, protein and vitamin $\mathrm{C}$ was carried out by employing the gravimetric method as adopted by the Association of Official Analytical Chemists (AOAC, 1990). This method gives an estimate of the indigestible fibre in the beverage. The insoluble residue is collected by filtration, dried, weighed and ashed to correct for mineral contamination of the fibre residue.

\subsubsection{Carbohydrate Test}

The carbohydrate test was carried out by measuring $1 \mathrm{ml}$ of the beverage sample into a test tube followed by the addition of $0.9 \mathrm{ml}$ of water and $5 \mathrm{ml}$ of concentrated sulphuric acid. These were mixed thoroughly and allowed to stand for a period of 30 minutes. The result was read on a spectrophotometer at a wavelength of $485 \mathrm{~nm}$ and compared with a calibration curve to calculate the carbohydrate content (AOAC, 1990).

\subsubsection{Test for Vitamin C}

Vitamin $\mathrm{C}$ was determined by measuring $2 \mathrm{ml}$ of the test sample into $100 \mathrm{ml}$ volumetric flask. $50 \mathrm{ml}$ of metaphosphoric acid was added to the flask content and was stirred for 10 minutes. The mixture was filtered using a Whatman filter paper. $20 \mathrm{ml}$ aliquot of the filtrate was transferred into a flask and titrated against $0.01 \mathrm{~N}$ iodine, using starch solution as indicator to blue black end point. This was used to determine the vitamin $\mathrm{C}$ content of the sample (AOAC, 1990).

\subsubsection{Test for Protein Content}

This was carried out by collecting a known weight of the sample and digested with $20 \mathrm{ml}$ of tetraoxosulphate VI acid. The digested sample was added to $8 \mathrm{ml}$ of distilled water and $2 \mathrm{ml}$ of Nesseler reagent. This was left for 20 minutes at room temperature for colour development and then read at $520 \mathrm{~nm}$ in a spectrophotometer. The result obtained was multiplied by a factor to convert to protein content (AOAC, 1990).

\section{Results and Discussion}

The total viable bacteria and fungi counts of the Hibiscus sabdariffa beverage obtained during processing and storage under ambient temperature are presented as shown in Table 1 . The result shows that the total variable count decreases sharply at first and then increases gradually up to the sixth day before decreasing again all through the storage period. There were no fungi detected at the beginning of the storage period, indicating that the heat applied during the processing has eliminated all the associated fungi. However, as the storage progresses, fungi were detected and the viable count followed the trend observed with the bacteria count. It is observed from Table 1 that ecological successions amongst the microorganisms exist. The period from 0-4 days were dominated by Bacillus sp., Staphylococcus sp. and Streptococcus sp. while Lactobacillus sp. and fungi dominated the late phase (Tables 2, 3, 4). 
Table 1. Microbiological quality changes in Hibiscus sabdariffa beverage during storage at $28^{\circ} \mathrm{C}$

\begin{tabular}{ccc}
\hline $\begin{array}{c}\text { Period } \\
\text { (days) }\end{array}$ & $\begin{array}{c}\text { Bacterial Count } \\
(\mathbf{C F U} / \mathbf{m l})\end{array}$ & $\begin{array}{c}\text { Fungal } \\
(\mathbf{C F U} / \mathbf{m l})\end{array}$ \\
\hline 0 & $1.4 \times 10^{6}$ & $\mathrm{ND}$ \\
2 & $2.5 \times 10^{2}$ & $1.1 \times 10^{1}$ \\
4 & $10.2 \times 10^{4}$ & $2.0 \times 10^{1}$ \\
6 & $11.5 \times 10^{6}$ & $3.1 \times 10^{4}$ \\
8 & $8.0 \times 10^{5}$ & $2.5 \times 10^{2}$ \\
10 & $6.5 \times 10^{4}$ & $1.5 \times 10^{2}$ \\
\hline
\end{tabular}

ND - Not detected.

Table 2. Characteristics used for the identification of bacteria isolates from Hibiscus sabdariffa beverage

\begin{tabular}{|c|c|c|c|c|}
\hline Characterization and Tests & Isolate A & Isolate B & Isolate $\mathbf{C}$ & Isolate D \\
\hline CULTURAL: SURFACE & Smooth & Smooth & Smooth & Smooth \\
\hline FORM & Circular & Spreading & Circular & Circular \\
\hline ELEVATION & Convex & Slightly Convex & Convex & Convex \\
\hline EDGE & Entire & Entire & Entire & Entire \\
\hline SIZE & $1-2 \mathrm{~mm}$ & $2-4 \mathrm{~mm}$ & $2-0 \mathrm{~mm}$ & $1-0 \mathrm{~mm}$ \\
\hline CHROMOGENESIS & Yellow & White & Creamy & Creamy \\
\hline OPACITY & Opaque & Slightly Opaque & Opaque & Opaque \\
\hline \multicolumn{5}{|l|}{ MORPHOLOGICAL: } \\
\hline GRAM STAIN & + & + & + & + \\
\hline CELL SHAPE & Cocci & Rods & Rods & Rods \\
\hline SPORE STAIN & - & + & + & - \\
\hline ARRAGEMNENT & Single/Clusters & Chains & Single & Single/Chains- \\
\hline MOTILITY & - & + & + & - \\
\hline \multicolumn{5}{|l|}{ BIOCHEMICAL: } \\
\hline CATALASE & + & + & + & - \\
\hline OXIDASE & - & - & + & - \\
\hline COAGULASE & - & - & - & - \\
\hline INDOLE & - & - & - & - \\
\hline METHYL RED & - & - & - & - \\
\hline VOGES PROSKAUER & + & + & - & - \\
\hline CITRATE UTILIZATION & + & + & + & + \\
\hline HYDROGEN SULPHIDE & - & - & + & - \\
\hline PHENYLALANIWE & - & - & - & - \\
\hline SUGAR UTILIZATION & - & & - & - \\
\hline GLUCOSE & AG & A & AG & $\mathrm{AG}$ \\
\hline LACTOSE & A & - & - & A \\
\hline MANNITOL & A & A & - & A \\
\hline PROBABLE ISOLATE & Staphylococcus sp. & Bacillus sp & Lactobacillus sp. & Streptococcus sp. \\
\hline
\end{tabular}

Key: + = Positive; - = Negative; $\mathrm{A}=$ Acid production; $\mathrm{AG}=$ Acid and gas Production. 
Table 3. Characterization of yeasts isolated from Hibiscus sabdariffa beverage

\begin{tabular}{|c|c|c|}
\hline Attribute & Isolate D (Result) & Isolate E (Result) \\
\hline $\begin{array}{l}\text { Appearance of culture in } \\
\text { medium }\end{array}$ & $\begin{array}{l}\text { White firm flat like mass on } \\
\text { potatoes Dextrose Agar }\end{array}$ & $\begin{array}{l}\text { Brown convex with irregular edge dull and } \\
\text { opaque in potato dextrose Agar (PDA) }\end{array}$ \\
\hline Hyphae Nature & Septate & No hyphae \\
\hline Conidiophores & $\begin{array}{l}\text { Neither conidiospore or } \\
\text { sporangiophore }\end{array}$ & Neither conidiophore or Sporangiophore \\
\hline Types of asexual spores & Arthrospores & Ascospores \\
\hline $\begin{array}{l}\text { Characteristic of asexual } \\
\text { spore head }\end{array}$ & $\begin{array}{l}\text { Hyphae breaks into arthrospore } \\
\text { at the tip }\end{array}$ & No spore head \\
\hline $\begin{array}{l}\text { Microscopic appearance of } \\
\text { spore head }\end{array}$ & $\begin{array}{l}\text { Oral aerial spores and } \\
\text { cylindrical submerged ones }\end{array}$ & $\begin{array}{l}\text { Spherical, globase and occurs in pairs or } \\
\text { singles }\end{array}$ \\
\hline No ascospores in asci & No ascospores & 1-Bascospores \\
\hline Type of budding & No budding & Multilateral budding \\
\hline Biochemical & NT & + \\
\hline \multicolumn{3}{|l|}{$\begin{array}{l}\text { Assimilation of carbon } \\
\text { compounds }\end{array}$} \\
\hline Glucose & NT & + \\
\hline Sucrose & NT & + \\
\hline Mallose & NT & + \\
\hline Lactose & NT & + \\
\hline \multirow[t]{2}{*}{ Mannitol } & NT & - \\
\hline & NT & - \\
\hline $\begin{array}{l}\text { Formation of } \\
\text { Pseudomycellium }\end{array}$ & & Absent \\
\hline Foot cell & - & Absent \\
\hline Rhiziod & - & Absent \\
\hline Probable Identity & Geotrichum sp. & Saccharomyces sp. \\
\hline
\end{tabular}

Key: NT - Not tested; - =Negative; + = Positive.

Table 4. Characteristics of mould species isolated from Hibiscus sabdariffa beverage.

\begin{tabular}{|c|c|c|c|}
\hline Attribute & Isolate (Result) A & Isolate (Result) C & Isolate (Result) D \\
\hline $\begin{array}{l}\text { Appearance of culture in } \\
\text { medium }\end{array}$ & $\begin{array}{l}\text { Freely branched greenish } \\
\text { mycelium in Potato Dextrose } \\
\text { Agar (PDA) }\end{array}$ & $\begin{array}{l}\text { Colony profusely branched } \\
\text { which appear brownish black }\end{array}$ & $\begin{array}{l}\text { White colony grow on } \\
\text { Potato Dextrose Agar } \\
\text { (PDA) }\end{array}$ \\
\hline Hyphae & Septate & Septate & Non-septate \\
\hline Nature of conidiophores & $\begin{array}{l}\text { Perpendicular septate that } \\
\text { branches toward the top }\end{array}$ & $\begin{array}{l}\text { Arises from foot cells } \\
\text { organised septate terminating } \\
\text { in a swollen vesicle }\end{array}$ & $\begin{array}{l}\text { Upright sporangiophore } \\
\text { connected by stolons }\end{array}$ \\
\hline Types of asexual spores & Conida & Conidia & Sporangiophore \\
\hline $\begin{array}{l}\text { Characteristic of asexual head } \\
\text { spore }\end{array}$ & $\begin{array}{l}\text { Sterigmata arising from } \\
\text { metule rear conidia in chains }\end{array}$ & Vesicles bearing in chains & $\begin{array}{l}\text { Dark pear shaped } \\
\text { sporangium on } \\
\text { hemispherical columella }\end{array}$ \\
\hline $\begin{array}{l}\text { Microscopic appearance of } \\
\text { sexual spore }\end{array}$ & Round light conidia in chains & $\begin{array}{l}\text { Brownish black conidia in } \\
\text { chains }\end{array}$ & $\begin{array}{l}\text { Small globose } \\
\text { sporangiosphore }\end{array}$ \\
\hline Production and type of spore & Ascospores & Ascospores & Zygospores \\
\hline Special features stolons & Absent & Absent & Present \\
\hline Rhizoids & Absent & Absent & Present \\
\hline Foot cells & Absent & Absent & Present \\
\hline Probable & Penicillum sp. & Aspergillus sp. & Rhizopus sp. \\
\hline
\end{tabular}


Table 5. $\mathrm{pH}$, and titratable acidity content of Hibiscus sabdariffa beverage during storage

\begin{tabular}{ccc}
\hline Period (days) & pH values & Titratable acidity (\%) \\
\hline Day 2 & 2.98 & 0.042 \\
Day4 & 2.78 & 0.045 \\
Day6 & 2.67 & 0.048 \\
Day8 & 2.62 & 0.058 \\
Day10 & 2.61 & 0.067 \\
\hline
\end{tabular}

Table 6. Proximate composition of Hibiscus sabdariffa beverage during storage

\begin{tabular}{ccccc}
\hline $\begin{array}{c}\text { Period } \\
(\mathbf{d a y s})\end{array}$ & $\begin{array}{c}\text { Carbohydrate } \\
(\mathbf{m g} / \mathbf{g})\end{array}$ & $\begin{array}{c}\text { Protein } \\
(\mathbf{m g} / \mathbf{g})\end{array}$ & $\begin{array}{c}\text { Vitamin C } \\
(\mathbf{m g})\end{array}$ & $\begin{array}{c}\text { Total soluble solid } \\
\mathbf{( \% )}\end{array}$ \\
\hline Day 0 & 0.03 & 0.29 & 0.18 & 0.01 \\
Day 2 & 0.06 & 0.34 & 0.31 & 0.01 \\
Day4 & 0.08 & 0.39 & 0.49 & 0.03 \\
Day6 & 0.09 & 0.44 & 0.56 & 0.04 \\
Day8 & 0.06 & 0.37 & 0.54 & 0.03 \\
Day10 & 0.04 & 0.35 & 0.48 & 0.02 \\
\hline
\end{tabular}

The effect of processing and storage on the properties of the beverage is presented as shown in Table 5. Table 5 shows that the $\mathrm{pH}$ decreased all through the storage period, indicating that the acidity increased throughout the period of storage. This result agrees with the finding of Olayemi (2011) which shows that the $\mathrm{pH}$ of the plant beverage is acidic with values of between 2.53 and 2.67. The result of the proximate composition of the beverage from the plant during storage is shown in Table 6. The total carbohydrate content, protein content, vitamin $\mathrm{C}$ content and total soluble solid increased gradually from the second day up to the sixth day and thereafter decreased gradually all through the remaining period of storage.

The results of the investigation as shown in Table 2, 3 and 4 indicate that Hibiscus sabdariffa beverage contained a reasonable percentage of bacteria and fungi population. The large number of bacteria and fungi may be due to the fact that the beverage is susceptible to bacteria and fungi contamination during the processing and storage stages. The lactic bacterial isolated from the beverage are Lactobacillus sp., Bacillus sp., Staphylococcus sp. and Streptococcus sp. (Table 2) while Aspergillus sp, Penicillium sp, Rhizopus sp, Geotrichum sp and Saccharomyces $s p$ were the fungi isolates (Table 4). This is in agreement with some earlier works carried out by Akinyosoye and Akinyele (2000). This result also agrees with earlier work carried out by Braide et al. (2012) where they identified the presence of some microorganism associated with the plant.

The presence of lactic acid bacteria is expected since they are mostly found in the fermentative mash. The presence of these lactic bacteria prevents the survival of other pathogenic microorganism since their ability to produce lactic acid reduces the $\mathrm{pH}$ of the food medium. The presence of these organisms is of advantage to the overall health quality of the beverage.

The presence of Streptococcus sp. and Staphylococcus sp may have been enumerated from the beverage as a result of the handlers since they are associated with hand, hair or nasal cavities. This could have been discharged into the preparation stage through sneezing or coughing. The handler could also have been a carrier of the organism and so easily distributes the organism. It is observed from this study that the presence of Baccilus $s p$. in the beverage could have resulted from the fact that it is a spore former and as such the spores were easily distributed and able to withstand high temperature and $\mathrm{pH}$ to fully germinate.

The fungal isolates found in the plant beverage could be traced to the time when the petals were either being harvested or stored. They may have produced spores, which were attached to the petals and overcome adverse condition during the preparation and finally germinated in the finished product. This may be responsible for the high count recorded in the late phase of the storage period. 
The carbohydrate contents in the beverage increased throughout the storage period (Table 6). This increase can be associated with the activities of the various organisms. Similarly, the increases in the protein content may be due to the release of bound protein associated with the microbial activities and the content of the microorganism themselves. The result therefore shows that the conversion of carbohydrate and protein to other products such as alcohol, acids and other metabolites may have contributed to the low $\mathrm{pH}$ and high titratable acidity recorded.

\section{Conclusion}

The general method for producing the beverage of the plant will always contain an unusually large population of fermentative beneficial organisms and very likely, some pathogenic microorganisms. The isolation of some of this pathogen such as Staphylococcus sp., Streptococcus sp. and Aspergillus sp. could be indicative of health risk, although this is not to cause extreme worries because their populations have been inhibited to an extent by the acid produced by the lactic acid bacteria. The risk associated with the beverage could be reduced if at all stages from harvesting to selling, good hygienic conditions are imbibed. If this is done, the rate of contamination will be reduced tremendously and hence Hibiscus sabdariffa drink could serve as a convenient substitute to carbonated drinks which may not be affordable by a lot of people.

\section{References}

Akinyosoye, F. A., \& Akinyele, B. J. (2000). Microorganisms associated with “zoborodo”, a Nigerian beverage. Nigerian Society of Microbiology Book of Abstract.

AOAC. (1990). Official methods of food analysis (15th ed.). Association of Official Analytical Chemists, Washington DC., USA.

Braide, W., Oranusi, S., \& Peter-Ikechukwu, A. I. (2012). Perspectives in the hurdle techniques in the preservation of a non alcoholic beverage, zobo. African Journal of Food Science and Technology, 3(2), 46-52.

Cheesbrough, M. (2002). Medical laboratories manual for tropical countries (1st ed.). Butterworth Kent, London,.

FIIRO. (2011). Industrial profile on zobo drink production and preservation, FIIRO Publication 2014. Retrieved from http://www.manufacturingtoday.com.ng

Lin, T., Lin, H., \& Chen, C. (2007). Hibiscus sabdariffa extract reduces seru cholesterol in men and women. Nutritional Research, 27, 140-145.

McKay, D. L., Chen, C. O., Saltzman, E., \& Blumberg, J. B. (2010). Hibiscus Sabdariffa L. Tea (Tisane) Lowers Blood Pressure in Prehypertensive and Mildly Hypertensive Adults. The Journal of Nutrition. http://dx.doi.org/10.3945/jn.109.115097

Olayemi, F., Adedayo, R., Muhummad, R., \& Bamishaiye, E. (2011). The nutritional quality of three varieties of Zobo (Hibiscus sabdariffa) subjected to the same preparation condition. American Journal of Food Technology, 6, 705-708. http://dx.doi.org/10.3923/ajft.2011.705.708

Peter E., Mashoto, K. O., Rumisha, S. F., Malebo, H. M., Shija, A., \& Oriyo, N. (2014). Iron and Ascorbic Acid content in Hibiscus sabdariffa Calyces in Tanzania: Modelling and Optimization of Extraction Conditions. International Journal of Food Science and Nutrition Engineering, 4(2), 27-35.

Sengupta, R., \& Banik, J. K. (2011). Evaluation of Hibiscus sabdariffa leaf mucilage as a suspending agent. International Journal of Pharmacy and Pharmaceutical Sciences, 3(5), 184-187.

Sie, R. S., Charles, G., Diallo, H. A., Kone, D., Toueix, Y., Dje, Y., \& Branchard, M. (2011). Breeding of Hibiscus sabdariffa L.: Evaluation of resistance to Fusarium oxysporum Schlecht. Emend. Snyd. and Hans in two varieties. Agriculture and Biology Journal of North America, 2(1), 125-133.

Sulaiman, F. A., Kazeem, M. O., Waheed, A. M., Temowo, S. O., Azeez, I. O., Zubair, F. I., ... Adeyemi, O. S. (2014). Antimicrobial and toxic potential of aqueous extracts of Allium sativum, Hibiscus sabdariffa and Zingiber officinale in Wistar rats. Journal of Taibah University for Science, 8(4), 315-322. http:dx.doi.org/10.1016/j.jtusci.2014.05.004

\section{Copyrights}

Copyright for this article is retained by the author(s), with first publication rights granted to the journal.

This is an open-access article distributed under the terms and conditions of the Creative Commons Attribution license (http://creativecommons.org/licenses/by/3.0/). 